\title{
WSPÓŁCZESNY DYSKURS NEOEURAZJATYZMU ROSYJSKIEGO WOBEC EUROPY ŚRODKOWO-WSCHODNIEJ
}

\author{
MAREK JEDLIŃSKI ${ }^{1}$ \\ (Uniwersytet im. A. Mickiewicza w Poznaniu)
}
Słowa kluczowe: Rosja, Ukraina, Europa Środkowo-Wschodnia, neoeurazjatyzm, prawosławie, konserwatyzm

Keywords: Russia, Ukraine, Central-Eastern Europe, orthodox church, conservatism, neo-Euroasianism

\begin{abstract}
Abstrakt: Marek Jedliński. WSPÓŁCZESNY DYSKURS NEOEURAZJATYZMU ROSYJSKIEGO WOBEC EUROPY ŚRODKOWO-WSCHODNIEJ. „PORÓWNANIA” 16 (2015). T. XVI. S. 31-46. ISSN 1733-165X. W artykule poddano analizie i interpretacji założenia ideowe współczesnego, rosyjskiego neoeurazjatyzmu, liderem którego jest Aleksander Dugin - znaczący reprezentant rosyjskiego konserwatyzmu, o rosnących wpływach politycznych $\mathrm{w}$ kręgach najwyższych władz państwowych. W tekście eksponowane miejsce zajmuje prowadzony przezeń dyskurs ideowy wobec Europy Środowo-Wschodniej oraz Duginowska interpretacja konfliktu rosyjsko-ukraińskiego. Postuluje on zbudowanie ideokratycznego państwa prawosławno-radzieckiego, w skład którego wejść powinna Ukraina i Europa Środkowa. Lider neoeurazjatyzmu operuje językiem konfrontacji i wykluczenia, absolutyzując aksjologicznie obserwowaną rzeczywistość. Odpowiednich narzędzi do zinterpretowania i oceny zorganizowanego przez absurd, świata Dugina dostarcza twórczość literacka Wiktora Jerofiejewa i jego najnowsza powieść Akimudy.
\end{abstract}

Abstract: Marek Jedliński. CONTEMPORARY DISCOURSE OF RUSSIAN NEO-EURASIANISM AGAINST CENTRAL-EAST EUROPE. “PORÓWNANIA" 16 (2015). Vol. XVI. P. 31-46. ISSN 1733-165X. In my article I am analyzing and interpreting ideological foundations of contemporary Russian neo-Euroasianism. This movement is lead by Alexander Dugin - an important representative of Russian conservatism, whose political influences among circles of highest state authority have been growing lately. I focus mainly on Dugin's ideological discourse towards Central-Eastern Europe and on his interpretation of Russian-Ukrainian conflict. What he postu-

\footnotetext{
${ }^{1}$ Correspondence Address: marekjedliński@poczta.onet.pl
} 
lates, is to build an ideocratic orthodox-soviet state, which should include Ukraine and Central Europe. Dugin uses confrontational and excluding language, thus axiologically absolutizing perceived reality. I have extracted my methodological tools from writings of Victor Yerofeyev, especially his book "Akimudy", and used them for interpreting and evaluating Dugin's world organized by absurdity.

Wnikliwa analiza retoryki konfrontacji z Zachodem, dominująca w rosyjskich, oficjalnych i nieoficjalnych środkach masowego przekazu, mogłaby niezbyt dobrze zorientowanemu odbiorcy nasunąć myśl, że Rosja znajduje się $\mathrm{w}$ przededniu otwartego konfliktu zbrojnego z Zachodem. Potencjalnym agresorem miałby być oczywiście cały świat euroatlantycki. Obraz ten tworzony jest przez ośrodki podlegające kontroli Kremla dla realizacji bieżących celów politycznych. Jednocześnie druga strona konfrontacji informacyjnej nierzadko daje złudzenie ekskluzywności Zachodu, który rzekomo nigdy nie podjął działań o charakterze imperialnym, gwałcących prawo międzynarodowe. Należy również odnotować, iż uczestniczymy w kulturze, w której informacja poddawana jest obróbce (tabloidyzacji), traktowana jest jako produkt poddany regułom gry rynkowej (wedle których funkcjonują nie tylko media rosyjskie przecież). Konstrukcję mikroświata człowieka narusza nadpodaż informacji, budowanie napięcia na użytek masowego (uzależnionego od wirtualnych rozrywek) odbiorcy, ukazywanie oczom widzów nagłych zwrotów akcji, prezentowanych z naiwnością, wespół z niewysublimowaną analizą paranaukową. W ten sposób jednostka partycypująca w określonej kulturze traci, pod wpływem innych stron interakcji, poczucie zaufania, w efekcie rozpada się istotny dla niej schemat działania, dający możliwość wchodzenia w interakcje bez wymogu ciągłego definiowania kontekstu. Ów wyłaniający się świat ufundowany jest na ciągłej zmianie, burząc bezpieczeństwo ontologiczne (ontological security), konstytuowane - jak pisał Anthony Giddens - przez „poczucie trwania i porządku zdarzeń" (Giddens 314). Refleksja naukowa winna wyznaczyć standardy interpretacji i rozumienia zachodzących wydarzeń. Jednakże zaangażowanie ideowe (tudzież ideologiczne) elit intelektualnych utrudnia dokonanie oceny obserwowanych faktów z perspektywy stanowiska względnie niezależnego obserwatora; względnie, albowiem zadanie przeprowadzenia $w$ pełni zdystansowanej oceny trudne jest do wykonania nawet $\mathrm{w}$ warunkach znaczącego, temporalnego oddalenia horyzontu przedmiotu badawczego. Tymczasem, kiedy badacz partycypuje $\mathrm{w}$ określonej kulturze zadanie owo jest złożone, jako że musi wybrać jedną z perspektyw aksjologicznych. Wiedza, a już ex definitione rozumienie i interpretacja nie są wolne od wartości. Nie istnieją neutralne aksjologicznie epistemologie. Jednak naukowiec winien być świadom, iż postawa zaangażowania wartościuje na sposób bezpośredni. Powyższe konstatacje zakrawają na truizm, lecz warto uprzytomniać ich 
znaczenie. Próbę okiełznania chaosu współczesności można odnaleźć na przykład $\mathrm{w}$ przestrzeni paradygmatu historiozoficznego. Unaocznia on, iż obserwowane, gwałtowne przemiany polityczne nie muszą mieć trwałych następstw, a pozornie mało istotne zdarzenia mogą być brzemienne w skutkach. Wobec tego przestrzenią rejestrowania zmian fundamentalnych będzie szeroki odcinek temporalny, cały proces historyczny.

W tym kontekście aktualny kryzys rosyjsko-ukraiński po upływie kilku lat może pozostać tylko badawczym przedmiotem akademików; ale z drugiej strony: może być on dopiero początkiem kolejnego procesu rozszerzania stref wpływów i ekspansywnej polityki rosyjskiej wobec sąsiadów. Wyłania się tutaj głębszy problem - związany ze sposobem myślenia jednostek i całego społeczeństwa, wybierających władze i udzielających im swego poparcia. Kwestia ta wymagałaby drobiazgowego opracowania, co najmniej na poziomie obszernego studium. W niniejszym krótkim szkicu można się jedynie podjąć próby zasygnalizowania złożonego uwarunkowania społeczno-politycznego rzeczonej kwestii. Rozpad ZSRR zaskoczył społeczeństwo, wydarzenia historyczne niejako wyprzedziły zmiany mentalne - radziecka, wielka narracja trwale ukształtowała obraz świata znacznej części Rosjan. Niewykluczone jednak, że owa narracja ustąpi miejsca nowej wizji Rosji, zaproponowanej przez pokolenia młodych Rosjan: państwa $\mathrm{z}$ otwartą, nieskorumpowaną gospodarką, aktywnie uczestniczącego we wspólnym (z resztą świata) pokojowym rozwiązywaniu problemów globalnych. Jednak dotychczasowa retoryka świadczy o niepogodzeniu się z rozpadem dawnego imperium. Władze i media rządowe operują językiem epoki radzieckiej: konfrontacji, poczucia zagrożenia i szowinizmu. Przykładowo, w rosyjskiej telewizji publicznej wielokrotnie pojawiał się motyw jedynego mocarstwa nuklearnego, zdolnego zniszczyć Stany Zjednoczone; ożywiono również ducha wielkiej wojny ojczyźnianej: walecznej Rosji otoczonej zewsząd przez zdrajców i wrogów (aktualnie: przez ukraińskich neonazistów). Z kolei znany akademik, Andriej Fursow, z emfazą przekonuje w swych wykładach o ukraińskim faszyzmie napierającym na Rosję. W dyskursie wobec Ukrainy zastosowano sprawdzone chwyty propagandy radzieckiej: wszelkie niepokoje społeczne $w$ krajach Układu Warszawskiego miały być inicjowane przez niedobitki nazistowskie. Tym samym przeszłość została niejako archetypicznie uobecniona.

W najnowszej powieści Wiktora Jerofiejewa Akimudy, napisanej w 2012 roku, znaleźć można wiele trafnych antycypacji i celnych diagnoz, zaskakująco odpowiednio korespondujących z bieżącymi wydarzeniami politycznymi. Autor w całej powieści rozwinie opis inwazji na Rosję nieistniejącego państwa o nazwie Akimudy. W istocie jest to inwazja nieboszczyków, czyli atak rosyjskiej przeszłości na samą Rosję: „Akimudy są bowiem w nas samych" (Jerofiejew 176) - uprzytomnia pisarz czytelnikom. Na Rosję napadły jej czasy minione. Sztab generalny był przygotowany na agresję ze strony Zachodu i nie przewidział nieboszczyków jako po- 
tencjalnych wrogów Rosji - wyjaśnia Jerofiejew. Trupy poczęły się wydostawać nawet z murów kremlowskich, skandując hasła "Rosja dla martwych”, a "nad Placem Czerwonym przelatywały cienie przeszłości" (Jerofiejew 23). I to one stanowią największe niebezpieczeństwo: nie Europa, nie „ukraińscy neofaszyści”. Świat zewnętrzny nie może stwarzać zagrożenia dla imperium opanowanego przez upiory przeszłości: „Rosjanie spodziewali się ataku z powietrza. W południe zawyły syreny. Moskwianie, klnąc na czym świat stoi, leniwie powlekli się do metra. Jednak atak nastąpił spod ziemi" (Jerofiejew 13). Poczym rosyjski prozaik z właściwym sobie turpistycznym upodobaniem na ponad czterystu stronach przedstawia bieg zdarzeń, negliżując się przed czytelnikiem (nieco natrętnie) autobiograficznymi scenami, pełnymi zwulgaryzowanej seksualności i śmierci:

Na moich oczach rozpadły się ściany. Rozgrzebując rękami rumowisko, skacząc z sufitu, wyłażąc ze ścian, na peron wdarli się nieboszczycy, wydzielający straszliwy smród. Najpierw w dziurze pękniętej ściany pojawiła się czaszka o pustych oczodołach. Potem przecisnął się cały szkielet $\mathrm{z}$ dyndającymi kawałkami gnijącego mięsa i strzępami ubrania. Nieboszczycy [...] rzucili się na zebranych w podziemiu; [...] zaczęli rozszarpywać ludzi na kawałki, wywlekać z wagonów, [...] odrywać głowy i pić krew. Na mnie rzuciły się trzy krzepkie dziewuchy, chwyciły za gardło, zawirowały w dzikim sadystycznym tańcu i natychmiast zażądały, żebym zaprowadził je do eleganckiej restauracji [...]. Przemknęło mi przez głowę, że może są to moje zmarłe kochanki... przecież niektóre z nich już umarły? Wyglądały okropnie. Oczywiście nie poznawałem ich. Jak się nazywają? Czasem nie poznaję swoich żyjących przyjaciółek [...]. Objęci, wśród dzikich wrzasków, ruszyliśmy w górę po zakrwawionych stopniach [...]. Usiedliśmy przy stoliku. Ruda i inteligentka poszły do toalety. A ta z czarnymi włosami na łonie położyła kościstą dłoń na ręce [...] (Jerofiejew 16, 18, 19).

Powieść kończy się pozornym pokonaniem martwych: niby wszystko wraca do normy, tyle że prezydent (w powieści nazywany funkcyjnie Głównym) po popełnieniu samobójstwa, już jako martwy (nieśmiertelny), sprawować będzie stanowisko całą wieczność, a i sami żywi Rosjanie jakby zbratali się z nieboszczykami i wymieszali z nimi (zawiązywały się nawet pary mieszane: żywy-martwy). Treść książki Jerofiejewa organizowana jest przez absurd. Wielowątkowość, swoista neuroza przekazu wyznacza dynamikę ciągłych zmian okoliczności, w jakich znajdują się bohaterowie: świat Rosji w Akimudach to brutalny seks, klasztory, sadystycznie doświadczana śmierć, demoniczny śmiech i ukrzyżowanie przywódcy Akimudów na Placu Czerwonym. Jerofiejew dostarczył narzędzi, pozwalających mniej naiwnie zinterpretować intencje Kremla i przynajmniej częściowo odnaleźć się w rzeczywistości kreowanej przez władze Rosji. Pisarz umyślnie konstruuje szereg kłopotliwych dla czytelnika ambiwalencji, ekshibicjonistycznie oznajmiając, że rozumie Rosję, bo sam jest tak złożony, jak rosyjska ulica i władza: jest niepokorny, wulgarny i brutalny, jak reszta Rosjan; krytykowany zresztą z tego powodu 
przez feministki, liberałów, duchownych, komunistów i faszystów (Jerofiejew 56-57). Rosja ufundowana jest na maksymalizmie, ekstremizmie, „nie jest krajem, który lubi rozwiązania umiarkowane" (Jerofiejew 333-334) - wyjaśnia Jerofiejew. Właściwie do inwazji Akimudów Rosjanie byli niejako przygotowani, "dobrze wytresowani", nauczeni rozwiązywać „spiskowe rebusy samodzielnie” (Jerofiejew 16). Konspirologia stała się rosyjską grą narodową:

Kimkolwiek byłby moskwianin, jego filozofia życiowa opiera się na nieu fności [...]. Moskwianie uważają, że w tajemnicy władzy kryje się cała matrioszka innych tajemnic. Nieufność i podejrzliwość, z czasem przechodzące w stan maniakalny, to fundament ekstremizmu moskwianina, zarówno lewicowego, jak i prawicowego. Historycznie ukształtował się cały szereg ludzkich typów: przygłupy, hultaje, bezzębni emeryci. Ale stopień nieużywalności moskiewskiego intelektu leży poza granicami rozumu (Jerofiejew 217).

W oczach Jerofiejewa cała Moskwa-Rosja uzależniła się od taniego, ale jakże skutecznego narkotyku, jakim jest satysfakcja z dobrze rozpracowanego spisku. Rosja nie może również żyć bez konfliktu, „żywi się konfliktem, płodząc i pożerając wrogów" (Jerofiejew 357). Rosja jest jednocześnie niczym rozkapryszone dziecko, tupaniem wymuszające na reszcie świata to, na co ma w danej chwili ochotę. A cały świat jej ustępuje, bojąc się, ażeby ze złości nie wpadła w histerię, w szale rzucając we wszystkich swymi zabawkami. Teraz krzykiem wymusza Ukrainę, bo wcześniej ktoś zabrał jej cały Związek Radziecki. Rosyjski prozaik wyjaśnia niewtajemniczonemu europejskiemu odbiorcy, iż ciało Rosji „cierpi z powodu amputacji Związku Radzieckiego, po nocach bolą ją odcięte części ciała" (Jerofiejew 358). Przejawem zdziecinnienia jest wiara $\mathrm{w}$ mit, magiczne percypowanie rzeczywistości i oczywiście figle, dokazywanie na przekór dorosłym (dojrzałym). „Wy, Rosjanie, jesteście psotnicy!" (Jerofiejew 50) - powiedziała pani konsul na przyjęciu $\mathrm{u}$ ambasadora Akimudów. Rosja często robiła i robi psikusy Zachodowi: a to goszcząc z honorami Kim Dzong Ila, a to dając schronienie bratu Miloševića, a to dozbrajając Iran. Jerofiejew przekonuje czytelnika, że Rosja mityczna winna być właściwym przedmiotem refleksji; pochylenie się nad jej naturą da więcej odpowiedzi, aniżeli badania nad realnie istniejącym krajem o nazwie Rosja. Rosja mityczna to Rosja dziecinna właśnie, wierząca w cuda, ze wstrętem odnosząca się do wszelkich prób autorefleksji; to Rosja, która „z obezwładniającą naiwnością nie uwzględnia interesów swoich sąsiadów, instynktownie uważając ich za swoich wasali" (Jerofiejew 358).

W dziejach Rosji strategia polityczna wobec najbliższych sąsiadów, niemal zawsze imperialna i ekspansjonistyczna (co właściwe nie tylko Rosji), podbudowywana była licznymi tworami kultury. Myśliciele, pisarze, akademicy z własnej woli lub pod presją tworzyli szereg mniej lub bardziej spójnych koncepcji, które wznosiły konstrukcję mitologii państwowej. Jak stwierdził Ernst Cassirer, mit jest 
jedną z najstarszych i największych potęg obecnych w cywilizacji ludzkiej; jest ściśle związany z wszelką aktywnością ludzką. Manifestuje się również w polityce, w tym współczesnej: „Przewaga myślenia mitycznego nad myśleniem racjonalnym jest oczywista w niektórych naszych nowoczesnych systemach politycznych" (Cassirer 13). Mit kreowany w obszarze polityki rzuca wyzwanie wszelkim regułom logiki: jest niekoherentny, kapryśny; a glebą, z której wypuszcza pędy, są głębokie pokłady ludzkiej emocjonalności - objaśnia Cassirer (Cassirer 29, 57). Mit jest $\mathrm{w}$ pewnym sensie niezniszczalny, uodporniony na argumenty racjonalne, nie można go skompromitować za pomocą sylogizmów. Jest wciąż żywy, podobnie jak magia „społeczna” - człowiek nowoczesny nadal w nią wierzy, choć przestał już dawno wierzyć $\mathrm{w}$ magię przyrody i często z pogardą odnosi się do świata wspólnot pierwotnych, w oczach których wszystkie moce ludzkie i wszystkie siły przyrody mogły się skoncentrować w czarowniku. Jednakże nawet we wspólnotach wczesnotradycyjnych, w których magia i mit rządzą i przenikają całość uczuć i życia wspólnoty, nie funkcjonują one zawsze w taki sam sposób ani też nie zawsze przejawiają się $\mathrm{z}$ taką samą siłą. Pełnię siły swego oddziaływania osiągały z chwilą, kiedy człowiek musiał bezpośrednio zmierzyć się z jakąś niebezpieczną sytuacją. Cassirer zwraca uwagę na uniwersalny wymiar magicznego i mitycznego postrzegania rzeczywistości, również $w$ jej uwspółcześnionym aspekcie politycznym:

Ten opis roli, jaką magia i mitologia pełnią w społeczeństwach, da się równie dobrze zastosować do wyżej rozwiniętych stadiów ludzkiego życia politycznego. W sytuacjach rozpaczliwych człowiek będzie się zawsze uciekał do desperackich środków, a nasze obecne mity polityczne noszą charakter takich środków [...]. Przez setki i tysiące lat w historii ludzkości panowała wiara, że dzięki umiejętnemu stosowaniu formuł magicznych i rytuałów człowiek może zmienić bieg przyrody. Pomimo wszystkich nieuchronnych frustracji i rozczarowań ludzkość wciąż rozpaczliwie, z całą siłą i uporem lgnęła do tej wiary. Nie ma się więc co dziwić, że w naszych działaniach politycznych i w naszym politycznym myśleniu magia wciąż zachowuje swoją pozycję (Cassirer 309, 327).

Współczesne rosyjskie mity polityczne ostateczną postać uzyskały w następstwie wielowiekowego wysiłku intelektualnego licznych autorów. Wykazywanie bezpośredniej korespondencji między ideami głoszonymi współcześnie a koncepcjami ukutymi $\mathrm{w}$ przeszłości może oczywiście budzić uzasadnione wątpliwości poznawcze. Rzetelność badawcza nakazuje uwzględniać różnice historyczne. Trudno jednak nie dostrzec wspólnych motywów tudzież elementów retorycznych. Aktualnie obserwowany rosyjski dyskurs konfrontacji wobec Zachodu wpisuje się $\mathrm{w}$ pewną, starannie opracowaną na rosyjskim Wschodzie, mitologię politycznej odrębności, wyją̨tkowości historycznej i misji. Warto w tym miejscu wspomnieć o, powstałym prawdopodobnie między rokiem 1037 a 1050, Stowie 
o Prawie i Łasce $^{2}$ - autorstwa metropolity Hilariona (Rusina, pierwszego nie-Greka na tronie metropolitarnym w Kijowie). Metropolita w swym hymnie pochwalnym opiewał przyjęcie Rusi pod szczególną opiekę Opatrzności. Hilarion pisał o świętej ziemi ruskiej, a biblijne pojęcie $l u d u$ Bożego utożsamił z ruskim ludem prawosławnym: „Ty jesteś bowiem Bogiem naszym, my zaś - Twoim ludem [...] nieodmiennie okazuj łaskawość swoją Twojemu ludowi" (Słowo o Bogu 57). W piśmiennictwie europejskim znaleźć można wiele zabytków literackich, zawierających mit wyjątkowości, ale bodaj żaden naród - wyjaśnia znawca kultury rosyjskiej, Sergiusz Zienkowski - nie pokusił się, zaledwie kilkadziesiąt lat po przyjęciu chrztu, na zbudowanie koncepcji swej ekskluzywności polityczno-religijnej (Zen'kovskiy, $<$ http://www.sedmitza.ru>). Kolejny etap mitologizowania nastąpił w czasach, kiedy bieg historii uczynił już z Moskwy siłę unifikacyjną, zdolną zebrać ziemie ruskie i obronić ortodoksję. Bizancjum upadło, chrześcijaństwo wschodnie straciło wsparcie polityczno-militarne. Zaledwie ćwierć wieku później prawosławni Rusini zrzucą jarzmo tatarskie, co odczytane zostanie jako przejaw woli Opatrzności. Idea Moskwy-Trzeciego Rzymu zrodziła się nie tylko jako efekt konfrontacji z Zachodem, ale również jako negatywne odniesienie do tradycji greckiej. Wierzono, że Drugi Rzym (Konstantynopol) upadł krótko po przyłączeniu się do heretyków (unia florencka). Jako że Pierwszy Rzym (katolicki) skazany był na upadek, gdyż sprzeniewierzył się ortodoksji, Drugi zaś Rzym wsparł herezję, Opatrzność powierzyła Rusinom zadanie ochrony czystego chrześcijaństwa. Moskwa miała być Trzecim i ostatnim Rzymem. Myśl tę wyraził mnich Filoteusz w traktatach epistolarnych (lata 30-40-te XVI w.), nadając ostateczny kształt mitowi Moskwy-Trzeciego Rzymu: „[...] cesarstwo greckie zostało zburzone i nie odbuduje się: wszystko to zdarzyło się, gdyż zaprzedali prawosławną wiarę grecką katolikom" (Poslaniye o 449). Ruś Moskiewska (potem Rosja) miała się stać, zgodnie z wolą książąt moskiewskich, carów i duchownych, centrum świata prawosławnego, a że prawosławie postrzegano jako prawdziwe chrześcijaństwo, to miała stać się sercem świata chrześcijańskiego. Zbudowano opozycję Rosja prawosławna a reszta świata, zamknięto się $\mathrm{w}$ ekskluzywizmie i przeciwstawiono nie tylko światu pogańskiemu, islamskiemu czy łacińskiemu, ale nawet prawosławnemu-niemoskiewskiemu (Hauke-Ligowski 487). Następne stadium tworzenia mitów politycznych zlokalizować można w wieku XIX. W dziejach Rosji dziewiętnaste stulecie nazywane jest złotym wiekiem kultury rosyjskiej: w literaturze pięknej, muzyce, sztuce i myśli filozoficznej tego okresu rozpoznać można zintensyfikowane po-

2 Pełen tytuł brzmi następująco: O Prawie danym przez Mojżesza, i o łasce i prawdzie, które się staty przez Jezusa Chrystusa; o tym, jak Prawo doszto do swego kresu, łaska zaś i prawda napetnita ziemię wszystka, wiara dotarta do każdego narodu, w tym także do narodu naszego ruskiego (przekład Ryszarda Łużnego). Metropolity Iłariona Stowo o Prawie i łasce. W: Stowo o Bogu i człowieku. Myśl religijna Stowian Wschodnich doby staroruskiej. Wybrał, przełożył i opracował Ryszard Łużny. Kraków 1995, s. 39. 
szukiwania tożsamości narodowej. Była to jednocześnie epoka dalszej ekspansji polityczno-militarnej Imperium. Dojrzałym kierunkiem ideowym, odwołującym się do tradycji prawosławnej i mocno akcentującym potrzebę zbudowania konkurencyjnego wobec Zachodu kręgu kulturowego (przy zachowaniu postawy dialogicznej), było słowianofilstwo klasyczne lat trzydziestych i czterdziestych, reprezentantami którego byli Iwan Kiriejewski, Aleksy Chomiakow i Konstanty Aksakow. Andrzej Walicki - polski znawca myśli rosyjskiej, autor obszernej monografii poświęconej słowianofilstwu - wyrażał jednak wątpliwość, czy aby w ogóle postawa dialogiczna była w tym nurcie obecna. Szczególnie schyłkowa faza słowianofilstwa klasycznego dostarczyła licznych dowodów na jego dogmatyzm. Polski badacz nazwał Chomiakowa "nacjonalistą-mocarstwowcem”, "człowiekiem zachłystującym się wizją zwycięstw militarnych i pomnażania potęgi państwa”, który "dął w fanfary, upajał się szowinistycznym entuzjazmem” (Walicki 136). W drugiej połowie wieku XIX. słowianofilstwo zaczęło ulegać - jak pisał myśliciel Włodzimierz Sołowjow - "degeneracji”, stając się projektem „reakcyjno-archeologicznym" (Solov'yev 433), otwierając drogę dla wojujących postaw panslawistycznych i skrajnie zachowawczych (m.in. Mikołaja Danilewskiego). Po początkowym kosmopolityzmie komunizmu $\mathrm{w}$ wersji radzieckiej nastąpiła ponura epoka wąskiego nacjonalizmu (szczególnie w okresie zimnowojennym). Równolegle część rosyjskich intelektualistów emigracyjnych w okresie międzywojnia tworzyła na Zachodzie nurt umysłowy, który określano mianem eurazjatyzmu. Liczne frakcje tego kierunku intelektualnego (zrzeszające historyków, muzyków, geografów, filozofów) łączyło przekonanie o wyjątkowości kultury rosyjskiej, rzec można - jej wyższości nad europejską, oraz misja zbudowania wielkiego imperium prawosławnego (Massaka 135). Przypuszczać można, że gdyby eurazjaci, miast komunistów, panowali na Kremlu, prowadziliby nie mniej imperialistyczną politykę względem swych sąsiadów. Można również przyjąć założenie, że niemal wszystkie $\mathrm{z}$ wymienionych koncepcji polityczno-historyczno-ideowych odwoływały się do zwykłej siły, brutalnej ekspansji. To mit polityczny wyznaczał na ogół kierunki owej ekspansji. Im bliżej Moskwy, tym bliżej pętli mitu, zaciskanej już realnie przez władzę państwową. Znacząca część Europy Środkowej zawsze pozostawała w jakimś stopniu w cieniu owego moskiewskiego mitu, Wschodnia zaś (szczególnie Ukraina) była jego częścią. Dlatego próby rozerwania go przez Ukraińców nie mogły się spotkać z bezczynnością obrońców całej, wielowiekowej mitologii moskiewskiej. W świadomości dziewiętnastowiecznej (a nawet dwudziestowiecznej) Moskwy Ukraina funkcjonowała jako część Wielkiej Rosji, jako byt Mniejszy od Rosji. Lider współczesnego neoeurazjatyzmu - Aleksander Dugin - sposób postrzegania Ukrainy wyraził tymi słowy: „Ukrainy jako państwa narodowego historycznie nigdy nie było: ani etnosu ukraińskiego, ani narodu ukraińskiego ani cywilizacji ukraińskiej" (<http://ekklezia.ru>). Przyłączenie Ukrainy do świata Zachodu oznaczałoby powstanie ogromnej wyrwy w samym sercu Europy 
Wschodniej; byłby to zamach na rosyjskość, na rosyjski mit polityczny. Dugin przekonuje, że państwowość spadła na Ukraińców zupełnie przypadkowo, ,jako efekt zamroczenia starszego brata"; Rosjanie w chwili upadku ZSRR nie wiedzieli, co czynią, lecz „teraz pijane lata zdrady i upadku minęły, Rosja wytrzeźwiała i zastanawia się, co zrobić z przepitymi [...] ziemiami" (<http://ekklezia.ru>).

Przytoczona wypowiedź Dugina ukazuje założenia ideowe neoeurazjatyzmu, czyli nurtu polityczno-ideowego, będącego kontynuacją eurazjatyzmu międzywojnia. To właśnie Aleksander Dugin jest głównym inicjatorem ambitnego projektu odrodzenia założeń eurazjatyzmu emigracji rosyjskiej. W latach dziewięćdziesiątych traktowany był jako ekscentryczny intelektualista, o niewielkim znaczeniu; dziś jest znaczącym teoretykiem rosyjskiego tradycjonalizmu, akademikiem, doradcą przewodniczącego Dumy Państwowej, częstym gościem programów publicystycznych i telewizyjnych. To postać złożona, zagadkowa, cynicznie bądź lekkomyślnie rzucająca agresywne i populistyczne hasła. Dugin jest autorem blisko czterdziestu monografii naukowych ${ }^{3}$ - ich wartość naukowa może budzić uzasadnione wątpliwości poznawcze: treść jego książek i artykułów jest nachalnie tendencyjna, chaotyczna i pełna sprzeczności, co utrudnia interpretację i zmusza do zachowania dystansu intelektualnego wobec jego prac.

Aleksander Dugin jest reprezentantem tradycjonalizmu. Doktryna ta ufundowana jest (między innymi) na religijnym - używając terminu Karla Mannheima - stylu myślenia (Mannheim 645). Kultura rosyjska po rozpadzie Związku Radzieckiego doświadczyła znaczącego rozkwitu myśli religijnej, natomiast ostatnia dekada przyniosła dodatkowo zintensyfikowane działania Cerkwi, zmierzające do zawarcia z władzą świecką trwałego sojuszu ideowego. Władze rosyjskie, chcąc zasypać powstałą po rozpadzie imperium radzieckiego przepaść ideologiczną, chętnie przystąpiły do programowego zakorzeniania w społeczeństwie światopogladu prawosławnego, przy jednoczesnym rozbudzaniu nostalgii radzieckiej. Nota bene, dowodzi to, jak powierzchowny był proces sekularyzacji w Związku Radzieckim i w jakim stopniu konserwatywny, zachowawczy, tradycjonalistyczny i nacjonalistyczny był komunizm (przynajmniej w wymiarze deklaratywnym nazywany komunizmem) w wersji rosyjskiej. Można odnieść wrażenie, że bieżącą rosyjską politykę wewnętrzną i zagraniczną zdominowała retoryka właściwa tradycjonalistom. Tradycjonaliści i stronnicy neoeurazjatyzmu mogą więc wywierać pośrednio wpływ również na kierunki polityki zagranicznej Rosji. Jeśli przyjąć za uprawnioną tę hipotezę, to miałoby to przełożenie na politykę rosyjską wobec sąsiadów Rosji, a szczególnie Ukrainy. Trudno oszacować stopień zaangażowania

\footnotetext{
${ }^{3}$ Najważniejsze prace Dugina: Puti Absolyuta (1990), Konservativnaya revolyutsiya (1994), Osnovy Geopolitiki (1997), Osnovy Yevraziystva (2002), Filosofiya Voyny (2004), Proyekt Yevraziya (2006), Chetvertaya politicheskaya teoriya (2009), Teoriya mnogopolyarnogo mira (2012).
} 
i stan świadomości ideowej elity politycznej i intelektualnej Rosji i samego prezydenta Putina, ale język, jakim operują władze Rosji, pozwala rozpoznać wiele elementów wspólnych konstrukcji myślowych tak Kremla, jak i neoeuazjatyzmu. Wspólnota ideowa Putina i Dugina opierałaby się na trzech filarach: na antyliberalizmie, antyokcydentalizmie oraz prawosławiu. Dugin postuluje zaprowadzenie porządku teokratycznego, czyli - jak deklaruje - religijne uorganizowanie kultury, moralności i polityki. „Prawosławie - naszą jedyną drogą" - oznajmia lider neoeurazjatyzmu (<http://www.sorokinfond.ru>).

Duginowskie hasła zbudowania ideokratycznego, wspólnotowego, prawosławnego i sowiecko-faszystowskiego zarazem państwa prawdy jawią się niczym egzotyczne fantazmaty, ale konfrontacja owego produktu wybujałej wyobraźni ekscentrycznego intelektualisty z rzeczywistością społeczno-polityczną współczesnej Rosji zmusza do uważnego wczytania się w koncepcje rosyjskich tradycjonalistów. Trudno nie rozpoznać w Rosji kultu radzieckości, któremu towarzyszy radykalizacja postaw konserwatywno-religijnych (,Stalin [...] żyje w naszych cerkiewnosłowiańskich komunistach", Jerofiejew 240). Przetrwała imperialno-totalitarna predylekcja do zmilitaryzowania, zuniformizowania sfery publicznej, czemu towarzyszy narastająca agresja wobec inności, wobec różnorakich mniejszości. Dugin od lat dziewięćdziesiątych wieści zaprowadzenie porządków konserwatywnej rewolucji (polityka wewnętrzna) i pozbieranie rozrzuconych części dawnego imperium (polityka zagraniczna). Europa Środkowo-Wschodnia stanowiła strategiczny obszar dawnego imperium. Odzyskanie kontroli nad znaczącą jej częścią jest conditio sine qua non powodzenia dalszej ekspansji polityczno-militarnej, która winna uczynić z Rosji imperium o wymiarze globalnym.

W projekcie Duginowskim terytorium Rosji ma być niemal centrum świata, sercem kontynentu (heartland). Lider neoeurazjatyzmu posłużył się terminem heartland, którego twórcą był angielski badacz Haldorf Mackinder. W koncepcji geopolitycznej Mackindera Azja, Afryka i Europa, tworząc wielka wyspę (ląd), przeciwstawione zostały reszcie świata oceanicznego. Heartland angielski geograf sytuował w północno-wschodniej części wielkiego kontynentu eurazjatyckiego. Dla Dugina hipoteza Mackindera, stanowiąca, iż kto włada heartlandem, ten włada całą Eurazją i Afryką, a tym samym jest w stanie władać całym światem, stała się fundamentem konstruktów teoretycznych neoeurazjatyzmu. Duginizm, postulujący wzmacnianie eurazjatyckiej potęgi lądowej, jest swoistą odpowiedzią na amerykańską, geopolityczną koncepcję Sea Power (Jean 74-78). Antagonizmy rosyjsko-amerykańskie wypływają - w świetle doktryny neoeurazjatyckiej - z rywalizacji między światem Morza a światem Lądu; okoliczności historyczno-polityczne sprawiły, iż aktualnie liderami pierwszego są Stany Zjednoczone, drugiego zaś Rosja. Dugin rozpoznaje w świecie wielką wojnę kulturowo-cywilizacyjną: między liberalno-indywidualistycznym Zachodem a religijno (tradycjonalistyczno)-wspólnotowym Wschodem. 
Warto odnotować, iż rzeczony motyw konfliktu dwóch światów pojawił się również $\mathrm{w}$ najnowszych artykułach Dugina $\mathrm{w}$ kontekście kryzysu rosyjsko-ukraińskiego. Lider neoeurazjatyzmu stwierdza, że dzisiejsza Ukraina stała się areną starcia cywilizacji Morza (świata euroatlantyckiego) z cywilizacją Lądu (czyli z Rosją). W artykule Szósta kolumna wyjaśnia Dugin, że serce cywilizacji Lądu bije w Rosji, a przylegające do niej regiony (np. Ukraina) mogą ciążyć albo ku cywilizacji Morza, albo Lądu. Oczywiście zadaniem Moskwy jest przyłączenie tych regionów (<http://vz.ru/opinions/2014>).

W przekonaniu Dugina nadrzędnym, strategicznym celem najbliższych lat winno być rozbicie sojuszu Stanów Zjednoczonych z Europą Zachodnią (rozbicie NATO), przy jednoczesnym skłócaniu państw członkowskich Unii Europejskiej. Demontaż jedności euroatlantyckiej i Unii Europejskiej otworzy możliwość rozpoczęcia ekspansji militarno-politycznej przez Rosję na kraje obecnie znajdujące się w orbicie wpływów amerykańskich i unijnych, w tym między innymi krajów Europy Środkowej i Wschodniej. Warto w tym miejscu odnotować, że Dugin dość często zmieniał swą wizję Europy Środkowo-Wschodniej, włączając do regionu różne kraje i narody - na próżno doszukiwać by się u niego konsekwencji i jednej definicji.

Koncepcje geopolityczne Dugina dojrzałą postać uzyskały w monumentalnej pracy Podstawy geopolityki. Przyszłość geopolityczna Rosji, opublikowanej w roku 1999. Zawarł w niej wiele nierealnie brzmiących postulatów i planów strategii politycznej Rosji na arenie międzynarodowej, aczkolwiek aktualna sytuacja na Ukrainie zmusza do uważnego pochylenia się nad treścią książki Dugina, zwłaszcza, że stała się niemal obowiązkową lekturą na akademiach wojskowych i na wielu niewojskowych uczelniach wyższych. Dugin kreśli w niej wizję wyparcia wpływów amerykańskich (atlantyckich) z Europy Środkowej poprzez ścisły sojusz między Moskwą a Berlinem. Bezpieczeństwo w trakcie budowania imperium eurazjatyckiego miałyby zapewnić Rosji również porozumienia z Tokio i Teheranem. Z tym ostatnim - zdaje się sugerować Dugin - sojusz miałby charakter tymczasowy: służący najpierw ostatecznemu zachwianiu pozycji geopolitycznej Stanów Zjednoczonych na Bliskim Wschodzie, a następnie otwierający Rosji (po pokonaniu Iranu) wrota do skarbu pełnego czarnego złota oraz Oceanowi Indyjskiemu, owemu światu ciepłych mórz, który chcieli już opanować ostatni imperatorzy rosyjscy (Dugin 1999: 241). Trudno nie odnieść wrażenia, że Dugin przyobleka się w szaty porywczego młodzieńca, amatora-stratega, rozstawiającego na starej, dziewiętnastowiecznej mapie modele drewnianych żołnierzyków.

Lider neoeurazjatyzmu politykę zagraniczną pojmuje w kategoriach ciągłej ekspansji, rozszerzania stref wpływów, w końcu konfliktu i otwartej konfrontacji, uzasadnianej argumentacją historyczno-ideową. Europa Środkowo-Wschodnia jawi się dlań jako ważny element przyszłego imperium eurazjatyckiego. Konkre- 
tyzując, Europa Środkowa winna zostać podzielona między Niemcy a Rosję. Potężne, lądowe Niemcy rywalizują z proamerykańską Wielką Brytanią, co wzmacnia szansę na zawarcie strategicznego sojuszu między Moskwą a Berlinem - przekonuje Dugin (Dugin 1999: 35). Wytyczenie w Europie Środkowo-Wschodniej stref wpływów między Rosją a Niemcami da tym ostatnim - jak stwierdza Dugin - możliwość trwałego wyzwolenia się od wpływów Stanów Zjednoczonych. Dugin projektuje dominację na Zachodzie Niemiec, a na Wschodzie Rosji. Neoeurazjata przywołał postać niemieckiego geopolityka Karla Haushofera: orędownika ścisłego porozumienia niemiecko-rosyjskiego $\mathrm{w}$ obszarze polityki międzynarodowej. Haushofera i Dugina połączyła wrogość do świata anglosaskiego. Niemiecki strateg wyraził opinię, że konflikty niemiecko-rosyjskie były nadzwyczaj lekkomyślne i dały mocarstwom anglosaskim możliwość opanowania przeważającej części globu (Dugin 1999: 70-71). Na załączonych w książce Podstawy geopolityki mapach lider neoeurazjatyzmu zakreślił zamaszyście (zresztą niezbyt starannie) strefy wpływów: do strefy niemieckiej włączył Polskę, Litwę, Łotwę, Estonię, Czechy, Słowację, Węgry, Austrię, Słowenię, Bośnię i Hercegowinę, Chorwację, niewielką część Ukrainy (tę greckokatolicką i najbardziej nacjonalistycz$n q$ - wedle słów Dugina) oraz Czarnogórę. Aleksander Dugin, z emfazą przemawiając do wyobraźni czytelnika, pełen odwołań historycznych, bezceremonialnie przedstawia plan włączenia znaczącej części regionu Europy Środkowej do Rosji, argumentując, iż prawosławny żywioł słowiański zrozumieć i uporządkować może jedynie imperium rosyjskie. Dugin nie jest oczywiście konsekwentny i deklarowany początkowo klucz wyznaniowy (pomocny przy wyznaczaniu stref wpływów) porzuca, powodowany już koniec końców wyłącznie imperializmem: włącza wobec tego do rosyjskiej strefy wpływów Rumunię, Bułgarię, Grecję, Serbię, Macedonię, a nawet prawie całe terytorium Finlandii oraz muzułmańską w większości Albanię (Dugin 1999: 346-348). Oddanie części Europy Środkowej we władanie Niemiec jest w oczach Dugina przykrą koniecznością, gdyż euroazjatyckie imperium rosyjskie po pierwsze nie będzie w stanie opanować Niemiec, po wtóre potrzebować będzie, w trakcie procesu tworzenia euroazjatyckiego mocarstwa, co najmniej neutralnych Niemiec - neutralność tę zagwarantować mogą wyłącznie ustępstwa terytorialne, czyli oddanie Niemcom znacznej części kulturowo łacińskiej Europy Środkowej, z którą prawosławna Rosja i tak miałaby dużo problemów. Wzmocnienie pozycji Niemiec oraz podział stref wpływów w Europie Środkowo-Wschodniej miałyby zabezpieczyć zachodnią cześć imperium euroazjatyckiego przed agresją świata atlantyckiego. Intencją Dugina jest rozbicie jednobiegunowego modelu świata (z dominującą rolą Stanów Zjednoczonych) i zaprowadzenie porządku dwubiegunowego (ewentualnie wielobiegunowego), w ramach którego Rosja zajmować ma pozycję podobną do tej, jaką posiadał ZSRR (Dugin 1999: 730). 
W tym kontekście Dugin nie ukrywa satysfakcji z majowego, wyborczego wyniku eurosceptyków, którzy w Brukseli będą nieświadomymi rzecznikami projektu zbudowania rosyjskiego imperium euroazjatyckiego. Eurosceptycy, wespół ze zwolennikami osłabiania wpływów amerykańskich w Europie, przyśpieszą również oddanie wykrwawionej Ukrainy w ręce Rosji. Ukraina - wedle słów Dugina skazana jest na długotrwałą wojnę domową, gdyż przebiega przez nią granica między tożsamością atlantycką a rosyjską. Dla Dugina jest jasne, że Europa nie wesprze Ukrainy, a nawet milcząco założyła jej powrót w orbitę wpływów Kremla. Neoeurazjata przekonuje, że Europa nie wchłonie nacjonalistycznie nastrojonej Ukrainy - stworzyłaby bowiem zagrożenie dla państw unijnych; Dugin bezceremonialnie oznajmia: „Neonazistowska Ukraina absolutnie nie jest potrzebna Europie" (<http://politobzor.net/show-27353-ukraina-v-rukah-gomoseksualistov>). Jednak we wcześniejszym tekście Majdan postrzegał Dugin jako przewrót zorganizowany przez siły Zachodu (głównie amerykańskie) w celu oderwania Ukrainy od Rosji, co miało pogrzebać euroazjatycki projekt ekonomiczny Putina (nabrał on ostatecznie ram prawnych 29 maja 2014 r.). Zjednoczenie rynków euroazjatyckich to jedno z kluczowych narzędzi rozbicia jednobiegunowego modelu świata - konkluduje autor artykułu Czarny maj (<http://ruskline.ru/opp >). W najnowszym wywiadzie dla BBC (lipiec 2014) Dugin ubolewa nad wahaniem Putina w kwestii Ukrainy: jego zdaniem "siły liberalne” próbują zwalczać „jastrzębie” i dlatego Putin opóźnia interwencję zbrojną. W roku 2008 lider neoeurazjatyzmu nawoływał również prezydenta Rosji do wojskowego zajęcia Gruzji. Dugin projektował wtenczas dalsze działania armii rosyjskiej, które zwieńczyć miało przyłączenie Krymu do Rosji (<http://evrazia.info>). Warto wspomnieć, że w trakcie kampanii 2008 roku wyruszył do Osetii Południowej i sfotografował się z przenośnym działem przeciwlotniczym na ramieniu, w marcu 2014 roku nawiązał natomiast kontakty z separatystami z południowo-wschodniej Ukrainy, udzielając im porad strategiczno-politycznych, a nawet taktyczno-wojskowych (<http://www.aboutru.com>).

Dugin argumentuje na sposób historyczny i mityczny, odwołując się do emocji. Kijów jest dlań kolebką państwowości ruskiej, Wielkim Początkiem przyszłego imperium rosyjskiego; a i dziś pozostaje Ukraina niezbędnym elementem projektu euroazjatyckiego Rosji. Dugin twierdzi, że Rosja dla dobra Ukrainy chce ją odciągnąć od zgnitego moralnie Zachodu. Lider neoeurazjatyzmu wpisuje cele geopolityczne w szerszą perspektywę cywilizacyjną: mowa o kierowanej przez Rosję misji odrodzenia religijnego Europy. Dlatego artykuł Czarny maj zakończył Dugin wezwaniem do jak najszybszego opanowania Ukrainy i rozpoczęcia triumfalnego marszu na Zachód, plastycznie przedstawiając obraz zepsutych płodów cywilizacji zachodniej, rozgniatanych przez gąsienice rosyjskich czołgów prawosławnej i konserwatywnej rewolucji (<http://ruskline.ru/opp>).

Wnikliwa analiza Duginowskiego języka zmusza do postawienia pytania, $\mathrm{w}$ jakim stopniu twórca neoeurazjatyzmu cynicznie stosuje zabiegi retoryczne, 
w jakim zaś autentycznie wyraża swą opinię. W licznych artykułach pisze Dugin o „ukraińskim zezwierzęceniu”, planowanym ludobójstwie milionów prorosyjskich obywateli Ukrainy, o wspieraniu przez Zachód ukraińskich mordów rytualnych na Rosjanach, o „amerykańskich, neonazistowskich marionetkach z Prawego Sektora” i ich „żydowskich sponsorach" (<http://www.inopressa.ru/article>). Autor kilkusetstronicowej Konspirologii jest obecnie aktywnym internautą-blogerem, wykorzystuje ów amerykański wynalazek wojskowy do promowania swych ekstatycznych, profetycznych wizji. Przestrzega Rosjan przed chytrym planem „żądnego krwi i terroru” Zachodu, dla którego Ukraina jest medium przeniesienia chaosu na teren Rosji. W wywiadzie udzielonym Krymskiej Prawdzie (koniec czerwca 2014 r.) Dugin bez obsłonek wyjaśnia, iż jego wcześniejsze tezy o zmowie antyrosyjskich sił liberalnych potwierdza fakt wyboru na prezydenta Poroszenki-Żyda oraz „ogromna liczba” aktywistów LGBT na Ukrainie. Dugin zaczarowuje rzeczywistość stwierdzając: „Mamy doświadczenie harmonijnej współegzystencji w Rosji Tatarów rosyjskich, doświadczenie Czeczenów, którzy walczyli z nami, a potem przeszli na naszą stronę [...]. To przyjaciele, którzy nie do końca rozumieją, że są przyjaciółmi" (<http://politobzor.net/show>). Dugin każde wydarzenie opisuje i objaśnia w kategoriach spisku. Pod koniec lipca 2014 r. umieścił w Internecie film z komentarzem wyjaśniającym przyczyny katastrofy malezyjskiego samolotu: kijowska junta strąciła samolot, aby wstrząśnięta opinia międzynarodowa wsparła zamysł dostarczania broni przez Amerykanów (<http://www.russiapost. su/archives $>$ ). Nota bene groteskowo wygląda na filmie brodaty Dugin, kiedy łącząc się $\mathrm{z}$ tzw. medialnym sztabem frontu południowo-wschodniego (Ukrainy), z emfazą mówi o „setkach ofiar krwawej junty kijowskiej” na tle domowych wersalek i sterty poduszek4. Pełne przekonanie Dugina o ukraińskiej odpowiedziałności za katastrofę samolotu podziela jednak Kreml. Zresztą sam Dugin coraz częściej nazywany jest głównym politologiem kremlowskim ${ }^{5}$.

Ów alians władzy z Duginem mógłby się wydawać trwały i nierozerwalny, gdyby nie paradoks, który kieruje myślami lidera neoeurazjatyzmu. W mało znanej szerszym odbiorcom książce pt. Archeomodernizm bodaj nieopatrznie uprzy-

${ }^{4}$ Dugin w kilku zamieszczonych w sieci filmach występuje odziany w koszulkę polo z logo marki Lacoste. We wspomnianym wywiadzie udzielonym Krymskiej Prawdzie ubolewa nad europejskim stylem ubierania się Rosjan. Namawia Dugin rodaków do zakupienia i noszenia tradycyjnego odzienia, jakie popularne było wśród rosyjskiego chłopstwa.

${ }^{5} \mathrm{~W}$ jego cieniu pozostaje inny strateg geopolityki - Igor Panarin. Obaj panowie uczestniczyli $\mathrm{w}$ uroczystym spotkaniu na Kremlu z okazji inkorporacji Krymu. Panarin jest akademikiempolitologiem, od lat siedemdziesiątych funkcjonującym w służbach specjalnych ZSRR (potem Rosji), wieloletnim uczestnikiem ciał eksperckich przy prezydencie Rosji i Radzie Federacji. Panarin operuje wyjątkowo naiwnymi konstrukcjami, zwycięstwo neoeurazjatyzmu rozumiejąc jako triumf Dobra. W przekonaniu Panarina idea mocarstwowości i dumy ożyła w roku 1999, kiedy premierem został Władimir Putin. Zob. I. Panarin, L. Panarina, Informatsionnaya voyna i mir. Moskva 2003, s. 350. 
tamnia Dugin, iż imperialny dyskurs wobec Ukrainy jest dowodem słabości cywilizacyjnej Rosji. Kolejne wcielenia rosyjskiego posłannictwa określił mianem dramatycznego poszukiwania tożsamości, natomiast koncepcję Moskwy-Trzeciego Rzymu nazwał swoistym rosyjskim syjonizmem (Dugin 2011: 99-101). Myśli te zupełnie nie korespondują z deklarowanym przezeń ukierunkowaniem tradycjonalistycznym. Z perspektywy innego Dugina kolejne postaci rosyjskiego imperializmu jawiłyby się jako element konstrukcji myślenia właściwego wspólnotom wczesnotradycyjnym: byłyby więc archetypami nieświadomości, zakorzenionymi w najstarszych modelach patriarchatu-matriarchatu, organizującego życie Rusinów, potem Rosjan. Autor znajduje, iż Rosjanie rozumują na sposób familiarny, opisują otoczenie w kategoriach więzów krwi - dlatego państwo i naród są rodziną, której woli należy się podporządkować. Obecnie prezydent nadal pełni rolę ojca - konstatuje Dugin. Treść książki porządkuje wielokrotnie eksplikowana myśl, iż Rosjanie zatrzymali się w stadium mentalności zbiorowej i nie doszli do epoki modernizmu.

Pani konsul w powieści Akimudy tymi słowy zwraca się do rosyjskiego agenta służb - Ignata Kurojedowa: „Przecież u was wszyscy udają! I myślą, że tego nie widać" (Jerofiejew 100). Być może wypowiedź ta w jakimś sensie obrazuje istotę Duginowskich deliberacji, pozwalając jednocześnie poddać w wątpliwość ich autentyczność. W wywiadzie dla Krymskiej Prawdy lider neoeurazjatyzmu niepostrzeżenie wskazuje również na możliwość złagodzenia obecnego napięcia międzynarodowego: otóż Rosja jest krajem głęboko skorumpowanym; korupcja jest dla Dugina synonimem okcydentalizmu, liberalizmu i przejawem postawy niepatriotycznej. Oligarchowie i biznesmeni mocno powiązani kapitałowo z Zachodem są zazwyczaj antyrosyjscy - konkluduje Dugin (<http://politobzor.net/show>). Większość Rosjan nie chce jednak powrotu proeuropejskich liberałów - ich rządy (za prezydentury Jelcyna) kojarzą się z gospodarczą zapaścią i gwałtownym spadkiem pozycji Rosji na arenie międzynarodowej. Dugin twierdzi, że Putin odradza imperium i przygotowuje wielką rewolucję konserwatywno-prawosławną (<http://politobzor.net/show >). Wiktor Jerofiejew z kolei przestrzega czytelników: „Niektórzy nasi przywódcy chcieliby pójść w ślady Teheranu. Prawosławna cywilizacja: sojusz Patriarchy, który w jednej chwili staje się duchowym przywódcą narodu, z Głównym - to zagrożenie dla mojego kraju, dla mnie samego" (Jerofiejew 350). Rosja - oznajmia rosyjski pisarz - właśnie wstaje z kolan; aby jednak dźwignąc do pionu - jak pisze - „tak duże cielsko”, niezbędne są kule imperialne. Sąsiadujące $\mathrm{z}$ nią kraje byłego ZSRR nie chciały dobrowolnie wystąpić w roli owych kul, wobec tego "Ruś obraziła się i zamknęła w sobie” (Jerofiejew 219). Kiedy się jednak obudziła, rozejrzała się dookoła i zapragnęła oprzeć się na najbliższym, ukraińskim sąsiedzie i wyprostować imperialnie. A Europejczycy? - zapytuje bohater powieści Akimudy, pisarz Samson-Samson; poczym odpowiada: „Zawsze byli tchórzami. Trochę pokrzyczą i zamkną mordy!” (Jerofiejew 374). 


\section{BIBLIOGRAFIA}

Cassirer, Ernst. Mit państwa. Przeł. A. Staniewska. Warszawa 2006.

Dugin, Aleksandr. G. Arkheomodern. Moskva 2011.

Dugin, Aleksandr. G. Osnovy geopolitiki. Geopoliticheskoye budushcheye Rossii. Moskva 1999, s. 241. Inne prace A. Dugina: Puti Absolyuta (1990); Konservativnaya revolyutsiya (1994); Osnovy Geopolitiki (1997); Osnovy Yevraziystva (2002); Filosofiya Voyny (2004); Proyekt Yevraziya (2006); Chetvertaya politicheskaya teoriya (2009); Teoriya mnogopolyarnogo mira (2012).

Giddens, A. Nowoczesność i tożsamość. "Ja" i spoteczeństwo w epoce późnej nowoczesności. Warszawa 2001. Hauke-Ligowski, A., OP. „Od „Świętej Rusi” do Imperium Rosyjskiego”. Znak 6 (1982) (331). S. 483-487. Jean, C. Geopolityka. Wrocław-Warszawa-Kraków 2003. S. 74-78.

Jerofiejew, Wiktor. Akimudy. Nieludzka opowieść. Przeł. M. Jagiełło. Warszawa 2014.

Mannheim, Karl. „Myślenie konserwatywne”. Elementy teorii socjologicznych. Materiaty do dziejów wspótczesnej socjologii zachodniej. Wybór i oprac. W. Derczyński, A. Jasińska-Kania, J. Szacki. Warszawa 1975.

Massaka, I. Eurazjatyzm. Z dziejów rosyjskiego misjonizmu. Wrocław 2001.

Panarin, I., Panarina, L. Informatsionnaya voyna i mir. Moskva 2003.

"Poslaniye o ne blagopriyatnykh dnyakh i chasakh". Pamyatniki literatury drevney Rusi. Konets XV pervaya polovina XVI veka. Red. L. A. Dmitriyev, D. S. Likhachev. Moskva 1984.

Stowo o Bogu i człowieku. Myśl religijna Stowian Wschodnich doby staroruskiej. Wybrał, przełożył i opracował Ryszard Łużny. Kraków 1995.

Solov'yev, V. S. Slavyanofil'stvo i yego vyrozhdeniye. W: idem, Sochineniya v dvukh tomakh. Moskva 1989.

Stremoukhov, D. Moskva - Tretiy Rim: istochnik doktryny. W: Iz istorii russkoy kul'tury. Kiyevskaya i Moskovskaya Rus'. Moskva 2002.

Novikova, L. I., Sizemskaya, I. N. „Idei messianizma v russkoy filosofii istorii”. Obshchestvennyye nauki $i$ sovremennost' 6 (1995). S. 70-71.

Walicki, Andrzej. W kreggu konserwatywnej utopii. Struktura i przemiany rosyjskiego stowianofilstwa. Warszawa 2002. S. 136.

Zen'kovskiy, S. A. "Russkoye staroobryadchestvo. Dukhovnyye dvizheniya semnadtsatovo veka”. München 1970. Podrozdział: Russkoye messianstvo. Web. 28.07.2014. <http://www.sedmitza.ru/ index.html?did=36286>

\section{Źródła internetowe}

Web. 21.07.2014. <http:// www.sorokinfond.ru/index.php?id=1164>

Web. 24.07.2014. <http://ekklezia.ru/blogi/3141-eto-velikaya-voyna-kontinentov-aleksandr-dugin-osobyitiyah-na-ukraine.html>

Web. 28.07.2014. <http:// politobzor.net/show-27353-ukraina-v-rukah-gomoseksualistov-i-evreyskiholigarhov.html $>$

Web. 27.07.2014. <http://ruskline.ru/opp/2014/05/7/chernyj_maj_ili_tanki_na_zapad>

Web. 28.07.2014. <http://evrazia.info/article/4839>

Web. 25.07.2014. <http://www.aboutru.com/2014/03/dugin>

Web. 22.07.2014. <http://www.inopressa.ru/article/07Jul2014/Giornale/dugin.html>

Web. 29.07.2014. <http://www.russiapost.su/archives/29318>

Web.17.07.2014. <http://vz.ru/opinions/2014/4/29/684247.html?utm_medium=twitter\&utm_source= twitterfeed $>$

Web. 28.07. 2014. <http://www.sedmitza.ru/index.html?did=36286> 